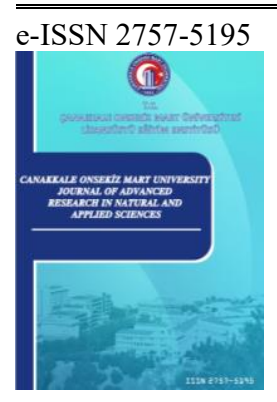

Çanakkale Onsekiz Mart University

Journal of Advanced Research in Natural and Applied Sciences

Open Access

\title{
Study on Okra (Abelmoschus esculentus L.) Response to Salt Stress Environment under Kabul Climatic Conditions, Afghanistan
}

\author{
Abdul Walid Salik ${ }^{1}$, Zafer Coşkun ${ }^{2, *}$, Mohammad Zaman Amini ${ }^{3}$ \\ ${ }^{1}$ Department of Soil Science and Irrigation, Faculty of Agriculture, Kabul University, Kabul, Afghanistan \\ ${ }^{2}$ Tekirdag Viticultural Research Institute, Tekirdag,Turkey \\ ${ }^{3}$ Department of Soil Science and Irrigation, Faculty of Agriculture, Kabul University, Kabul, Afghanistan \\ Article History \\ Received: $\quad 05.01 .2021$ \\ Accepted: $\quad 10.06 .2021$ \\ Published: $\quad 30.06 .2021$ \\ Research Article

\begin{abstract}
This research was conducted to determine the effects of saline-irrigation water on growth and yield of okra (Abelmoschus esculentus L.) under climatic conditions of Kabul Province, Afghanistan. This study consisted of control and three treatments having different salinity levels of irrigation water, $(\mathrm{T} 1: 0.0 \mathrm{mM}, \mathrm{T} 2: 5 \mathrm{mM}, \mathrm{T} 3: 10 \mathrm{mM}$, and T4: $20 \mathrm{mM}$, of $\mathrm{NaCl}$ concentrations), which were applied throughout the growing season of okra in plastic pots with a randomized complete block design. Results showed that increase in salinity levels caused a significant reduction in germination of seeds (T1: $98 \%$, T2: $80 \%$, T3: $63 \%$, T4: $53 \%$ ), leaf length (T1: $9.17 \mathrm{~cm}, \mathrm{~T} 2: 8.13 \mathrm{~cm}, \mathrm{~T} 3: 7$ $\mathrm{cm}, \mathrm{T} 4: 6.8 \mathrm{~cm})$, shoot height $(\mathrm{T} 1: 15.43 \mathrm{~cm}, \mathrm{~T} 2: 15.43 \mathrm{~cm}, \mathrm{~T} 3: 14.23 \mathrm{~cm}, \mathrm{~T} 4: 13.87 \mathrm{~cm})$ and root length $(\mathrm{T} 1: 15.37$ $\mathrm{cm}, \mathrm{T} 2: 12.73 \mathrm{~cm}, \mathrm{~T} 3: 9.03 \mathrm{~cm}, \mathrm{~T} 4: 8.7 \mathrm{~cm})$. Highest fresh pod weight was observed in T1 $(17.26 \mathrm{~g} / \mathrm{pot})$, followed by T2 (16.74 g/pot), T3 (11.93 g/pot) and T4 (7.75 g/pot). Water use efficiency (WUE) of okra was significantly affected by salinity levels. Greatest WUE $(13.08 \mathrm{~kg} / \mathrm{ha} / \mathrm{mm})$ was observed in T1, followed by T2 $(12.68 \mathrm{~kg} / \mathrm{ha} / \mathrm{mm})$, T3 $(9.04 \mathrm{~kg} / \mathrm{ha} / \mathrm{mm})$ and T4 $(5.87 \mathrm{~kg} / \mathrm{ha} / \mathrm{mm})$. As a result, okra growth and yield were significantly decreased with the increasing concentration of salt in the irrigation water.
\end{abstract} kra growth, salinity, salt stress, water use efficiency.

Keywords: fresh pod weight, okra growth, salinity, salt stress, water use efficiency.

\section{Introduction}

Soil salinity is a key challenge towards agricultural production in Afghanistan. Agriculture development plays a vital role in the economic development of the country. Okra has an essential nutritional value in Afghanistan and widely used in feeding throughout the country. Soil salinization is a serious challenge that restricts and decreases the growth and productivity of agriculture production all over the world. Worldwide, over 800 million hectares of soil have been influenced by salts (Ifediora, Edeoga \& Omosun, 2014). The existence of superfluous salt in water and soil is a serious environmental challenge (Ranga, Kumar, \& Darvhankar, 2019) which negatively influenced the development of plants (Elshaikh, Zhipeng, Dongli \& Timm, 2018, Kumar et al., 2017, Yakoubi, Babou, \& Belkhodja, 2019) and reduces the quantity and quality of agricultural products (Abbas et al., 2013). Rocks weathering, irrigation of land with saline-water, poor management of irrigation, high evaporation rate, continuous and irregular application of chemical fertilizers are known as the key factors of soil salinization (Kumari et al., 2019). The high concentration of salts increases the osmotic pressure, as result the root of the plant cannot absorb water (Shahid et al., 2011) also, a high salt concentration is poisonous within plant cells due to ionic stress and erode the balance of ions (Abbas et al., 2014). Vegetables play a significant role in the digestion of foods as well as contain large amounts of vitamins (Yohanna \& Muhammad, 2018) minerals, carbohydrates, and essential amino-acid (Benchasri, 2012). Furthermore, the fruit and leaves of okra contain a sufficient amount of water, fibre, phosphorus, calcium, iron, carbohydrates, protein, $\beta$-carotene and vitamins

\footnotetext{
1 (D) salik.abdulwalid@ku.edu.af

2 (iD) zafer.coskun@tarimorman.gov.tr

3 (iD) zamanamini@ku.edu.af

${ }^{*}$ Corresponding Author
} 
(Chowdhury \& Kumar, 2019) which can play the main role in abolishing malnutrition (Saleh, El-Gizawy, ElBassioumy , \& Ali, 2013; Fajinmi \& State , 2010; Nana et al., 2019). Okra is an economic vegetable, various parts of it such as leaf, stem, flower, fruit, and root can be used for different purposes (Chowdhury \& Kumar, 2019) as the fruit is used in a fresh and dry form in feeding, the root and branch are used in cleaning up the juice of sugarcane, as well as the leaf and stem are used in making of thread and rope (Abbas et al., 2014). Okra consumption has many health benefits, such as lowering blood sugar (Basharat, 2019), prevents skin dryness, lowers blood cholesterol, having anti-cancer characteristics, reduces anxiety and vomiting (Nomel \& Kerna, 2019; Adetuyi \& Ibrahim, 2014) regulates stomach and intestines function (Kumar, Ramjan, \& Das, 2019 ; Kumari, Rai, \& Das, 2019). Worldwide, the okra cultivation area exceeds one million hectares and its production is estimated at over six million tons (Basharat, 2019), in which India is known as a higher producer (Kumar, Ramjan, \& Das, 2019 ; Kumari, Rai, \& Das, 2019). Okra (Abelmoschus esculentus L.) is the member of Malvaceae (Sumudunie, Uluwaduge, Wijayabandara, \& Premakumara, 2019) and it is Originated from Africa (Miryam, Moulay, \& Narimane, 2015; Saleh et al., 2013). Currently, okra has grown widely in Tropical, Subtropical and Mediterranean regions (Sachini, Sutharsan, \& Srikrishnah, 2019; Yakoubi et al., 2019; Benchasri, 2012; Abid, Malik, Khalid, \& Wajid, 2002). Okra grows well in well-drained soil with loam texture, good organic matter content, and pH of 6 - 7.5 (Kumar et al., 2019). Okra required warm climate and the suitable temperature needs for its development is $20-30^{\circ} \mathrm{C}$ (Sachini et al., 2019; Vashi et al., 2019; Benchasri, 2012; Srivastava, Nath, \& Singh, 2015). Okra cultivation with the seedling method is less effective. Mostly, okra seeds are planted into the soil by hand or by machine above the stack. The suitable population of okra per hectare is 50000 to 60000 okra plants and 18 to $22 \mathrm{~kg}$ seed is using for cultivation (Kumar et al., 2019). The production of ten tons of okra fresh pod yield per hectare required $100 \mathrm{~kg}$ of nitrogen, $10 \mathrm{~kg}$ of phosphorus, $60 \mathrm{~kg}$ of potassium (Kumar et al., 2019), $80 \mathrm{~kg}$ of Calcium and $40 \mathrm{~kg}$ of Magnesium (Benchasri, 2012). Okra fresh pod yield is estimated between 10 to 12.5 tons per acre in the rainy season and 4 to 6 tons in the spring and summer seasons (Kumar et al., 2019). Ifediora et al., (2014), conducted a research on the negative impacts of saline irrigation water on the development and viscosity of okra pods. The key parameters of their study were germination percentage, length of stem and root, leaf size, weight of dry and fresh pod. Increasing salinity level had negative effects on okra growth. Yakoubi et al. (2019) carried out a research on okra germination response to gibberellic acid and abscisic acid under $\mathrm{NaCl}$ stress condition. Due to salt stress okra germination process delayed without altering the final rate but it adversely affected okra growth and fresh pod weight. Shahid et al. (2011) have been performed an search on the physiological and morphological response of okra under salt stress environment. Increasing salinity had inhibiting effects on photosynthesis rate, germination percentage, fresh pod weight, shoot, and root length. Abid et al. (2002) conducted study on the response of okra to combined effects of electrical conductivity of irrigation water (ECiw) and sodium absorption ration of irrigation water (SARiw). Okra growth, fresh pod weight, transpiration, and photosynthesis were decreased with improving levels of ECiw and SARiw. Emergence and germination tests are known as a significant screening tool for the assessment of okra tolerance to salt stress conditions (Abid et al., 2002). The purpose of this research is to determine the adversely effects of saline irrigation water on the growth and fresh pod yield of okra, as well as study the reaction of agronomic characteristics of okra against salinity.

\section{Materials and Methods}

\subsection{Materials}

This research was performed in the research farm of Agriculture Faculty of Kabul University which is located at Longitude $69^{\circ} 8^{\prime} 21^{\prime \prime} \mathrm{E}$ and Latitude $34^{\circ} 31^{\prime} 4^{\prime \prime} \mathrm{N}$ with an elevation of $1780 \mathrm{~m}$ above sea level. Seeds of okra, pH meter, electrical conductivity meter, hydrometer, plastic pots, sodium chloride, sieve, and ruler were used as research materials. The texture of the cultivated soil was loam, $\mathrm{pH}\left(\mathrm{pH}_{\mathrm{KCL}}=8.5\right)$, dissolved salts $(0.11 \mathrm{dS} / \mathrm{m})$, bulk density $\left(1.5 \mathrm{gr} \mathrm{cm}^{-3}\right)$ and according to the Munsell soil color chart, soil color was dark yellowish-brown (10YR $3 / 4)$. 


\subsection{Method}

The research was designed with three replications in randomized complete block design (RCBD). The soil was sieved by $2 \mathrm{~mm}$ sieve and $7.5 \mathrm{Kg}$ of topsoil was added to each plastic pot. Okra seeds were sown in the pots once the pots were filled with soil, the length of growing season was 130 days from early April to middle of August 2019. Immediately after sowing the seeds, the pots were irrigated with pre-determined saline water. Two weeks after sowing, thinning of okra took place and only 3 healthy plants were left in the pot and the remaining were discarded. Irrigation with saline water started immediately after sowing. Examined parameters in the study were germination percentage, leaf length, fresh pod weight, root length and shoot height of okra. Four levels of $\mathrm{NaCl}$ concentration were used as salt treatments. These treatments are $0.0 \mathrm{mM}$ as control or treatment 1 (T1), $5 \mathrm{mM}$ as treatment 2 (T2), $10 \mathrm{mM}$ as treatment 3 (T3), and $20 \mathrm{mM}$ as treatment 4 (T4). All four different levels of $\mathrm{NaCl}$ concentrations were used for irrigating okra plants along the cultivation season. Table 1 shows research treatment.

Table 1

Research treatments

\begin{tabular}{l|l}
\hline Treatments & Sodium Chloride Concentration (millimolar) \\
\hline T1 (control) & $0.0 \mathrm{mM}$ \\
T2 & $5 \mathrm{mM}$ \\
T3 & $10 \mathrm{mM}$ \\
T4 & $20 \mathrm{mM}$ \\
\hline
\end{tabular}

The measurements of seed germination recorded every three days. Leaf length, shoot height measurements taken place once in a week, okra fresh pod yield was collected gradually once in each four days, and root length was measured once at the final stage okra growth. Drip irrigation method was used in the study and irrigation was done once in each 5 days at the early stage of okra growing season, but later due to temperature increasing and accumulation of salt in the soil root zone, irrigation was done once in every 3 days. Okra was irrigated 24 times during the growing season. Every single frequency of irrigation contains $22 \mathrm{~mm}$ water, the total amount of applied irrigation water for the entire growing season was $528 \mathrm{~mm}$. Water use efficiency values were calculated from yield and irrigation water amount using the following formula:

Water use efficiency $(\mathrm{Kg} / \mathrm{ha} / \mathrm{mm})=$ Yield $(\mathrm{Kg} / \mathrm{ha}) /$ irrigation water $(\mathrm{mm})$

\subsection{Data Analysis}

The mean data from three replications were analysed by the method of one-way analysis of variance (ANOVA) using SAS statistical Software. Also, the means has been compared with the least significant difference test (LSD) for significant differences between the variables. The error bar is expressed to facilitate interpretation and comparison of results.

\section{Results and Discussion}

\subsection{Germination Percentage}

Salt stress significantly influenced the germination percentage. In this study, the germination process was completed within 7 days in the field condition. The germination percentage was decreased significantly when the salt concentrations were increased. Significant differences at $\mathrm{P}<0.05$ between different treatments have been observed except treatment levels $10 \mathrm{mM}$ and $20 \mathrm{mM}(\mathrm{F}=37.40, \mathrm{df}=3, \mathrm{P}=0.0003, \mathrm{LSD}=11.16)$. 


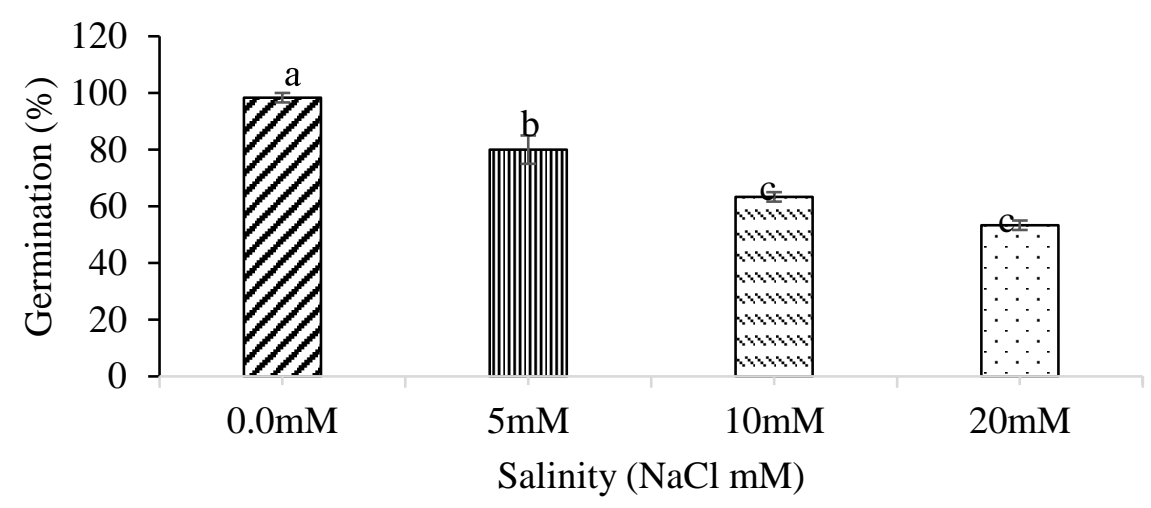

Figure 1. Response of germination rate (\%) to $\mathrm{NaCl}$ salt stress. Dissimilar letters show significant differences between treatments using the LSD test. Bars indicate standard error of the means.

It was observed that increasing salt level concentration in the irrigation water had adverse impact on the percent germination of okra seeds. The results indicate that treatment level $0.0 \mathrm{mM}$ had $98 \%, 5 \mathrm{mM}$ had $80 \%, 10 \mathrm{mM}$ had $63 \%$ while $20 \mathrm{mM}$ had $53 \%$ germination (Figure 1). Our findings also confirm the results of Ifediora, et al, (2014) and Abid et al., (2002), who observed a significant reduction in okra germination by increasing salt concentrations in irrigation water. High levels of salinity, especially $\mathrm{NaCl}$ can inhibit the germination rate due to toxic and osmotic effects (Miryam, Moulay, \& Narimane, 2015). In this study at treatment level $20 \mathrm{mM}$, the immature deaths of some plants were observed as well. It would be the effects of variation which occurred in cell division and cell elongation due to osmotic effects of saline water.

\subsection{Leaf Length}

The result of this study shows that there was considerable reduction in leaf length due to impact of salinity levels in the irrigation water. Significant difference at $P<0.05$ between treatments has been observed $(\mathrm{F}=17.11$, $\mathrm{df}=3, \mathrm{P}=0.0024, \mathrm{LSD}=0.9186$ ). The maximum reduction in leaf length occurred in treatment level $20 \mathrm{mM}$ $(6.8 \mathrm{~cm})$ followed by $10 \mathrm{mM}(7 \mathrm{~cm}), 5 \mathrm{mM}(8.13 \mathrm{~cm})$ and control $(9.17 \mathrm{~cm})$ (Figure 2). The reduction in leaf length as a result of high salt contents was mainly due to the osmotic effect of saline water. Leaf cells lose water because of an abrupt increase in soil salinity levels.

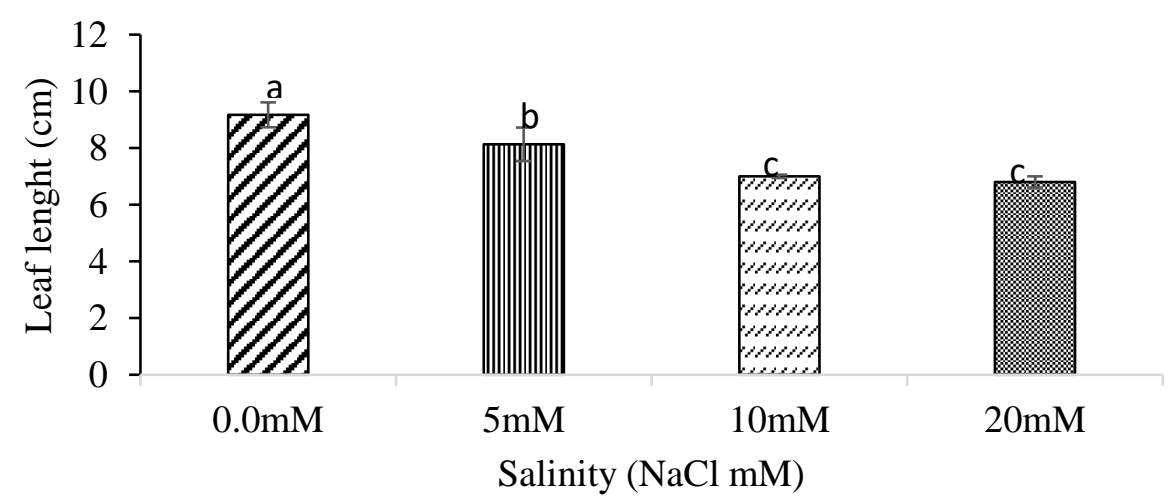

Figure 2. Response of leaf length $(\mathrm{cm})$ to $\mathrm{NaCl}$ salt stress. Dissimilar letters show significant differences between treatments using the LSD test. Bars indicate standard error of the means.

The decreasing cell division and cell elongation will drive to slower leaf appearance and shorter leaf length (Ifediora et al., 2014). Our findings can be confirmed by the results of Ifediora et al. (2014) where the leaf appearance and size become smaller under high concentration of salt in irrigation water which is similar to the findings of our study. 


\subsection{Shoot Height}

The result of this study shows that the shoot height of okra was negatively impacted as salt concentration increased in the irrigation water. As seen in Figure 3, there was not significant differences at $\mathrm{P}<0.05$ between treatments $0.0 \mathrm{mM}$ and $5.0 \mathrm{mM}$ and between $10 \mathrm{mM}$ and $20 \mathrm{mM}(\mathrm{F}=6.21, \mathrm{df}=3, \mathrm{P}=0.0286, \mathrm{LSD}=$ 1.1983). However, the first two treatments had significantly greater shoot length in compared the last two treatments, which had higher salt concentrations.

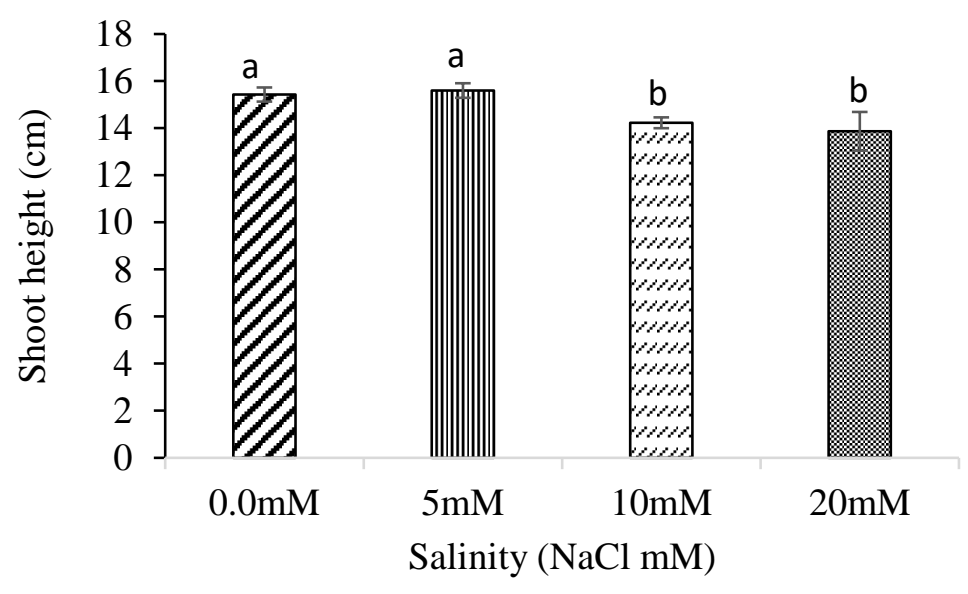

Figure 3. Response of shoot height $(\mathrm{cm})$ to $\mathrm{NaCl}$ salt stress. Dissimilar letters show significant differences between treatments using the LSD test. Bars indicate standard error of the means.

The greater shoot heights were observed in treatment level $5 \mathrm{mM}(15.6 \mathrm{~cm})$, followed by control treatment level $0.0 \mathrm{mM}(15.43 \mathrm{~cm})$, while the smaller shoot heights were observed in treatments $10 \mathrm{mM}(14.23)$ and 20 $\mathrm{mM}(13.87 \mathrm{~cm})$ (Figure 3). Our findings can be confirmed by results of Ifediora, et al., (2014) and Abid et al., (2002) who observed higher shoot height of okra plant under lower salt stress environment. In treatment level $5 \mathrm{mM}$, the okra might be fixed osmotically to the growing requirement, as a result, it had longer shoot height.

\subsection{Root Length}

Salt stress showed an inhibiting adverse effect on root length. Significant differences between treatments have been observed $(\mathrm{F}=87.45, \mathrm{df}=3, \mathrm{P}=0.0336, \mathrm{LSD}=1.2374)$. As is obvious in Figure 4, there were significant differences between all treatments except between treatments $10 \mathrm{mM}$ and $20 \mathrm{mM}$.

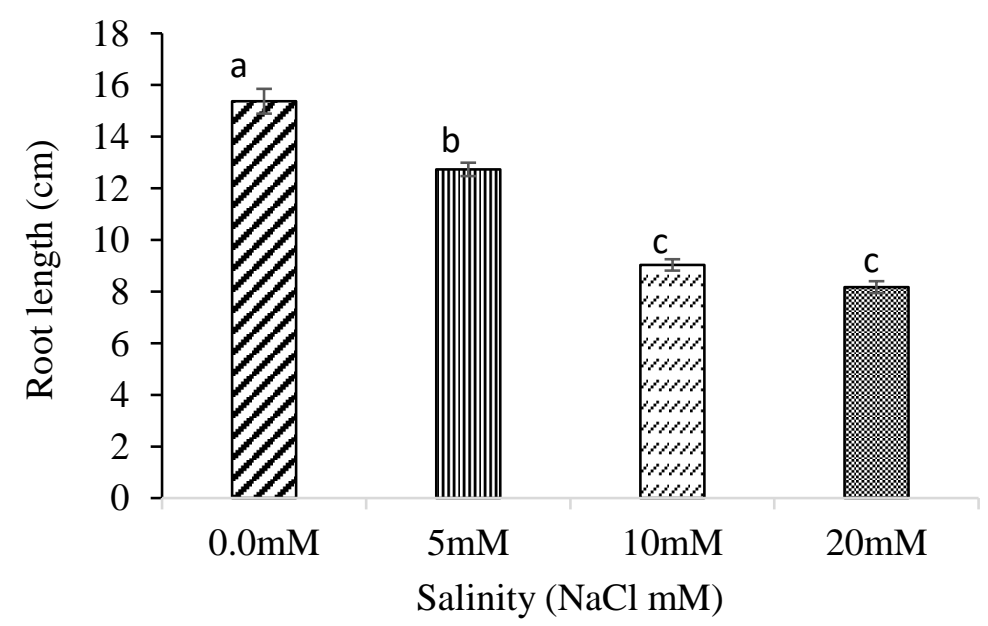

Figure 4. Response of root length $(\mathrm{cm})$ to $\mathrm{NaCl}$ salt stress. Dissimilar letters show significant differences between treatments using the LSD test. Bars indicate standard error of the means. 
The greatest reduction in root length was observed in treatment level $20 \mathrm{mM}(8.17 \mathrm{~cm})$, followed by $10 \mathrm{mM}$ $(9.03 \mathrm{~cm}), 5 \mathrm{mM}(12.73 \mathrm{~cm})$ and control $(15.37 \mathrm{~cm})$ (Figure 4). Similarities can be seen between our results and the findings of Ifediora et al, (2014) and Abid et al., (2002) where significant growth inhibition in root length was seen as salt concentrations increased. Irrigating with saline water might have caused an increase in osmotic pressure which can reduce cell elongation and limit root growth. The reduction in cell division and elongation could be due to the inhibiting impacts of salinity on growth-related hormones (Abbas et al., 2014). Under control treatment, the okra plant may be adjusted osmotically to growing conditions, as a result, they maintained successful cell enlargement resulting in maximum root length.

\subsection{Fresh Pod Weight}

Increase in salt concentration of irrigation water has adversely impacted the of fresh pods weight of okra. As shown in Figure 5, treatments $0.0 \mathrm{mM}$ and $5.0 \mathrm{mM}$ and treatments $10 \mathrm{mM}$ and $20 \mathrm{mM}$ did not statistically differ from each other at $\mathrm{P}<0.05(\mathrm{~F}=10.41, \mathrm{df}=3, \mathrm{P}=0.0086, \mathrm{LSD}=4.8029)$. However, the first two treatments resulted in significantly greater fresh pod weight in compared the last two treatments.

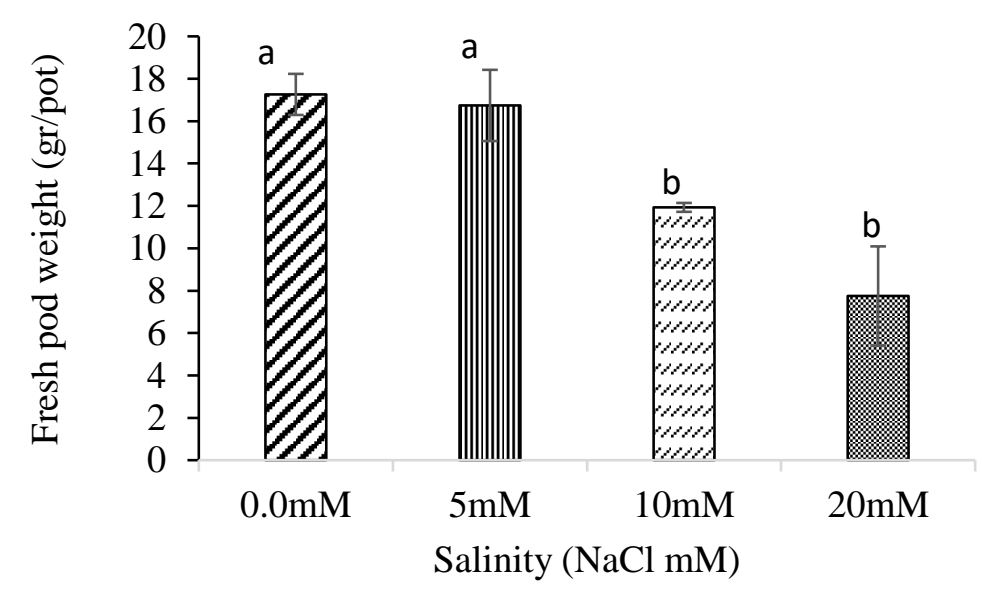

Figure 5. Response of fresh pod weight (gr) to $\mathrm{NaCl}$ salt stress. Dissimilar letters show significant differences between treatments using the LSD test. Bars indicate standard error of the means.

The maximum fresh pod weight was observed in treatment $0.0 \mathrm{mM}(17.26 \mathrm{~g} / \mathrm{pot})$, followed by treatments 5 $\mathrm{mM}$ (16.74 g/pot), $10 \mathrm{mM}(11.93 \mathrm{~g} / \mathrm{pot})$, and $20 \mathrm{mM}$ (7.75 g/pot). The results indicate a $3 \%, 31 \%$, and 55\% decrease in fresh pod weight under treatments $5 \mathrm{mM}, 10 \mathrm{mM}$, and $20 \mathrm{mM}$, respectively, compared to the control treatment. This means that increasing salt concentration in irrigation water can significantly reduce fresh pod weight of okra. The reduction in fresh pod weight can be due to the high soil salinity level causing a reduction in cell division, cell elongation, interrupted avoidance mechanism, and injury of plant cells. Our findings can be confirmed by results of Abid et al., (2002); Abbas et al. (2014) and Ifediora et al., (2014) who reported a significant reduction in fresh pod yield of okra by increasing salt concentrations. The summary of impacts of different salinity loves of irrigation water on germination percentage, leaf length, shoot height, root length, and fresh pod weight of okra is presented in Table 2.

\subsection{Water use Efficiency}

The impacts of salt concentration in irrigation water on water use efficiency (WUE) of okra is presented in Figure 6. The greatest WUE $(13.08 \mathrm{~kg} / \mathrm{ha} / \mathrm{mm})$ was observed under control treatment, followed by $5 \mathrm{mM}$ $(12.68 \mathrm{~kg} / \mathrm{ha} / \mathrm{mm}), 10 \mathrm{mM}(9.04 \mathrm{~kg} / \mathrm{ha} / \mathrm{mm})$ and $20 \mathrm{mM}(5.87 \mathrm{~kg} / \mathrm{ha} / \mathrm{mm})$. The difference between all treatments are statistically significant except between the first two treatments.

It is obvious that all irrigation water contains salts to some extent. These salts can supply essential nutrients for plants to grow and bear yield. However, if too much salt is supplied to the field, plant growth and 
performance will be adversely impacted. For examples, salt can accumulate in the soil, causing an "osmotic stress", or osmotic potential, which has the same effect on plants as a very negative matrix potential when the soil is dry, resulting is less available water for plants, which may inhibits plant germination and emergence. Meanwhile, if there is a disproportionate amount of magnesium, sodium, bicarbonate and/or carbonate in the water, the soil surface will seal up, causing infiltration problems. All these important parameters together adversely affect growth and performance of plants in the field.

Afghanistan is located in an arid region of the world and, in some parts of it, the farmers deal with saline soil and saline irrigation water. The salts can be imported to their field through a combination of water management problems, salt in the water, and sometimes fertilizer. Thus, under such conditions, it is very important for the farmers to practice reclamation irrigation to leach salts from the crop root zone. Proper planting method can also reduce salt effects. For instance, farmers can use furrow irrigation where they can shape the furrows so that salt-laden irrigation water evaporates at high points in the bed - and the plants/seeds are located at lower points. Applicant of drip irrigation, compared to surface irrigation types, can also minimize salt injury to plant as it frequently keeps the soil wet and the salts diluted.

Table 2

Effects of salt concentration in irrigation water on growth, leaf length, shoot height, root length, and fresh pod weight of okra.

\begin{tabular}{l|ccccc}
\hline \multicolumn{1}{c|}{ Treatments } & $\begin{array}{c}\text { Germination } \\
(\%)\end{array}$ & $\begin{array}{c}\text { Leaf Length } \\
(\mathrm{cm})\end{array}$ & $\begin{array}{c}\text { Shoot Height } \\
(\mathrm{cm})\end{array}$ & $\begin{array}{c}\text { Root Length } \\
(\mathrm{cm})\end{array}$ & $\begin{array}{c}\text { Fresh Pod } \\
\text { Weight }(\mathrm{gr})\end{array}$ \\
\hline Control $(0.0 \mathrm{mM})$ & $98.33 \pm 2.89^{\mathrm{a}}$ & $9.17 \pm 0.76^{\mathrm{a}}$ & $15.43 \pm 0.51^{\mathrm{a}}$ & $15.37 \pm 0.83^{\mathrm{a}}$ & $17.26 \pm 1.39^{\mathrm{a}}$ \\
$5 \mathrm{mM}$ & $90 \pm 8.66^{\mathrm{b}}$ & $8.13 \pm 1.03^{\mathrm{b}}$ & $15.6 \pm 0.53^{\mathrm{a}}$ & $12.73 \pm 0.45^{\mathrm{b}}$ & $16.74 \pm 2.41^{\mathrm{a}}$ \\
$10 \mathrm{mM}$ & $63.33 \pm 2.89^{\mathrm{c}}$ & $7 \pm 0.1^{\mathrm{c}}$ & $14.23 \pm 0.4^{\mathrm{b}}$ & $9.03 \pm 0.38^{\mathrm{c}}$ & $11.93 \pm 0.26^{\mathrm{b}}$ \\
$20 \mathrm{mM}$ & $53.33 \pm 2.89^{\mathrm{c}}$ & $6.8 \pm 0.35^{\mathrm{c}}$ & $13.87 \pm 1.42^{\mathrm{b}}$ & $8.17 \pm 0.4^{\mathrm{c}}$ & $7.75 \pm 3.12^{\mathrm{b}}$ \\
LSD & 11.169 & 0.9186 & 1.1983 & 1.2374 & 4.8029 \\
$\mathrm{CV}$ & 7.58 & 5.91 & 4.06 & 5.47 & 17.92 \\
$\mathrm{~F}$ & 37.40 & 17.11 & 6.21 & 87.45 & 10.41 \\
$\mathrm{P}$ & 0.0003 & 0.0024 & 0.0286 & 0.0336 & 0.0860 \\
\hline
\end{tabular}

Mean value indicated by the same letter in columns are non-considerable at 5\% level of significance, LSD at 5\% level of significance

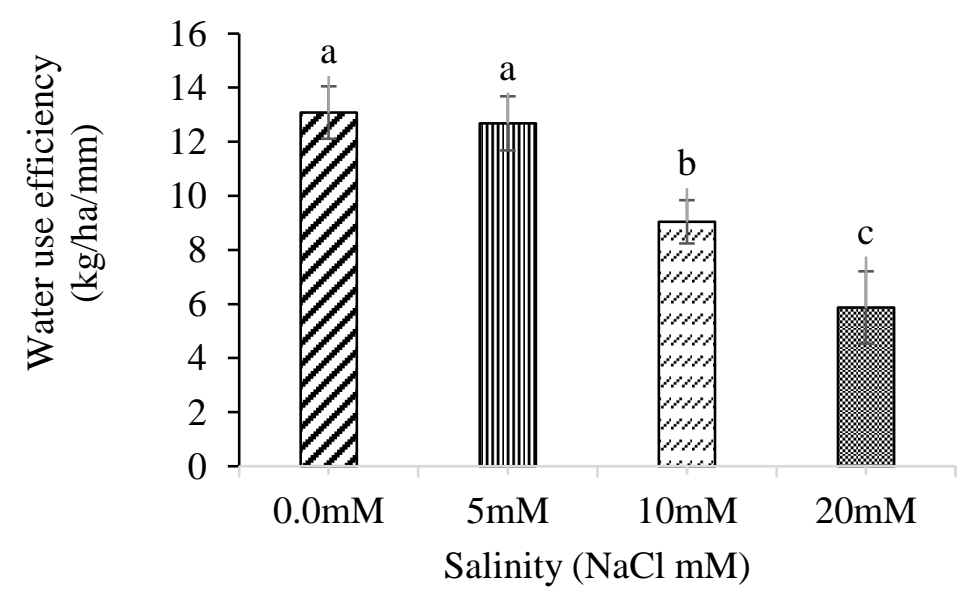

Figure 6. Water use efficiency. Dissimilar letters show significant differences between treatments using the LSD test. Bars indicate standard error of the means. 


\section{Conclusion}

According to the findings of this study, it can be concluded that a considerable reduction in germination percentage, leaf length, shoot height, root length, and fresh pod yield of okra strongly associated with salinity stress. These measured parameters can be accounted as an efficient tool for the evaluation of potential salinity endurance of okra. Indeed, the finding of this study can be confirmed by the results of recent researches where they found that the physiological functions, morphology, stomata closing as well as the photosynthesis rate of okra has been decreased due to the increasing level of salinity.

\section{Acknowledgement}

I would like to thank the researchers and my colleagues who contributed to conducting of experiments and the preparation of the article. I also would like to thank the department of soil science and irrigation, faculty of agriculture, Kabul university for supporting the study.

\section{Author Contributions}

Abdul Walid Salik: Conceived and designed the experiment.

Zafer Coşkun: Performed data collection and data analysis.

Mohammad Zaman Amini: Wrote up the paper.

\section{Conflict of Interest}

The authors declare no conflict of interest.

\section{References}

Abbas, T., Pervez, M. A., Ayyub, C. M., \& Ahmad, R. (2013). Assessment of morphological, antioxidant, biochemical and ionic responses of salt-tolerant and salt-sensitive okra (Abelmoschus esculentus) under Saline Regime. Pakistan Journal of Life and Social Sciences, 11(2), 147-153. Retrieved from: http://pjlss.edu.pk/pdf_files/2013_2/147-153.pdf

Abbas, T., Pervez, M. A., Ayyub, C. M., Shaheen, M. R., Tahseen, S., Shahid, M. A., Bilal, R. M. and, \& Manan, A. (2014). Evaluation of different okra genotypes for salt tolerance. College of Agriculture, University of Sargodha, Sargodha, Pakistan. International Journal of Plant, Animal and Environmental Sciences, 4(3), 23-30. Retrieved from: https://www.cabdirect.org/cabdirect/abstract/20143288358

Abid, M., Malik, S. A., Khalid, B., \& Wajid, R. A. (2002). Response of okra (Abelmoschus esculentus L.) to EC and SAR of irrigation water. Internatıonal Journal of Agriculture \& Biology, 4(3), 311-314. Retrieved from: https://citeseerx.ist.psu.edu/viewdoc/download?doi=10.1.1.1057.5457\&rep=rep1\&type=pdf

Adetuyi, F. O., \& Ibrahim, T. A. (2014). Effect of fermentation time on the phenolic, flavonoid and vitamin c contents and antioxidant activities of okra (Abelmoschus esculentus) Seeds. Nigerian Food Journal, 32(2), 128-137. DOI: https://doi.org/10.1016/S0189-7241(15)30128-4

Basharat, S. (2019). Beneficial effects of okra in diabetes mellitus. Asian Journal of Allied Health Sciences, $4(2), 67-77$.

Benchasri, S. (2012). Okra (Abelmoschus esculentus L.) as a valuable vegetable of the world. Ratarstvo $i$ Povrtarstvo, 49, 105-112. DOI: https://doi.org/10.5937/ratpov49-1172

Chowdhury, S., \& Kumar, S. (2019). Okra breeding: recent approaches and constraints okra breeding: recent approaches and constraints. Annals of Biology, 35(1), 55-60.

Elshaikh, N. A., Zhipeng, L., Dongli, S., \& Timm, L. C. (2018). Increasing the okra salt threshold value with biochar amendments. Journal of Plant Interactions, 13(1), 51-63. DOI: https://doi.org/10.1080/17429145.2017.1418914

Fajinmi, A., \& State, E. (2010). Incidence of okra mosaic virus at different growth stages of okra plants (Abelmoschus esculentus (L.) Moench) under tropical condition. Journal of General and Molecular Virology, 2(1), 28-31. Retrieved from: https://academicjournals.org/journal/JGMV/article-ab$\underline{\text { stract/E50998211032 }}$ 
Ifediora, H.N., Edeoga, H. O., \& Omosun, G. (2014). Effects of salinity on the growth and viscosity of fruits of okra (Abelmoschus esculentus L.). International Journal of Current Agricultural Research Vol., 1(7), 81-84. Retrieved from: https://www.semanticscholar.org/paper

Kumar, D., Al Hassan, M., Naranjo, M. A., Agrawal, V., Boscaiu, M., \& Vicente, O. (2017). Effects of salinity and drought on growth, ionic relations, compatible solutes and activation of antioxidant systems in oleander (Nerium oleander L.). Plos One, 12(9), 1-22. DOI: https://doi.org/10.1371/ journal.pone.0185017

Kumar, V., Ramjan, M., \& Das, T. (2019). Cultivation practices of okra. Biomolecule Reports, ISSN: 24568759, March, 0-5.

Kumari, R., Kumar, P., Meghawal, D. R., Sharma, V. K., Kumar, H., Avinashe, H., \& Al., E. (2019). Salttolerance mechanisms in plants (1st ed., Issue 1). AkiNik Publications. New Delhi, India.

Miryam, O., Moulay, B., \& Narimane, Z. (2015). Effect of salinity on seed germination of Abelmoschus esculentus. African Journal of Agricultural Research, 10(19), 2014-2019. DOI: https://doi.org/10.5897/AJAR2013.8341

Nana, R., Ma, Y., Ou, F., Kabor, B., Badiel, B., \& Tamini, Z. (2019). Effect of water quality on the germination of okra (Abelmoschus esculentus) seeds. International Journal of Agronomy, 2019, 1-7. DOI: https://doi.org/https://doi.org/10.1155/2019/4938349

Nomel, R., \& Kerna, N. A. (2019). Okra and the Heart: Reducing cardiovascular risk by lowering blood sugar with Okra. ECronicon Cardiology 6.12, 1(4), 1-5. Retrieved from: https://www.ecronicon.com/ eccy/pdf/okra

Rai, A. K. and, \& Das, H. (2019). Seed quality of okra produced after bio-priming seed quality of okra produced after bio-priming. International Journal of Current Microbiology and Applied Sciences, 8(6), 2166-2173. DOI: https://doi.org/10.20546/ijcmas.2019.806.257

Ranga, A. D., Kumar, S., \& Darvhankar, M. S. (2019). Effect of saline soil in okra plantation. Golden Jubilee International Salinity Conference, February, 132-133. DOI: https://doi.org/10.13140/ RG.2.2.19938.79046

Sachini, T., Sutharsan, S., \& Srikrishnah, S. (2019). Effect of different planting geometry and application of liquid organic fertilizer on the growth and yield of Abelmoschus esculentus L. intercropped with Vigna unguiculata L. International Journal of Sclentific \& Technology Research, 8(12), 1310-1314.

Saleh, M. A., El-Gizawy, A. M., El-Bassioumy, R. E. L., \& Ali, H. M. (2013). Effects of anti-coloring agents on blackening inhibition and maintaining physical and chemical quality of fresh-cut okra during storage. Annals of Agricultural Sciences, 58(2), 239-245. DOI: https://doi.org/10.1016/j.aoas.2013.07.008

Shahid, M. A., Pervez, M. A., Balal, R. M., Ahmad, R., Ayyub, C. M., Abbas, T., \& Akhtar, N. (2011). Salt stress effects on some morphological and physiological characteristics of okra (Abelmoschus esculentus L.) Salt stress effects on some morphological and physiological. Soil and Environment, 30(1), 66-73.

Srivastava, V., Nath, P., \& Singh, R. (2015). Screening of okra varieties against okra jassid (Amrasca biguttula biguttula Screening of okra varieties against okra jassid (Amrasca biguttula biguttula Ishida). Journal of Biotechnology and Crop Science, 4(4), 27-31. Retrieved from: http://www.jbcs.net.in/ AbstractDetail.aspx?Abst $=60$

Sumudunie, K., Uluwaduge, D., Wijayabandara, J., \& Premakumara, G. (2019). Okra (Abelmoschus esculentus), a possible intervention for diabetes. International Journal of Food Science and Nutrition, 4(5), 50-52. Retrieved from: http://www.foodsciencejournal.com/archives/2019/vol4/issue5/4-4-74

Vashi, J., Tandel, B., Saravaiya, S., Patel, A., Chaudhari, B., \& Al, E. (2019). Response of okra (Abelmoschus esculentus L.) to foliar application of silicon. International Journal of Current Microbiology and Applied Sciences, 8(08), 1277-1282. DOI: https://doi.org/10.20546/ijcmas.2019.808.150

Yakoubi, F., Babou, F. Z., \& Belkhodja, M. (2019). Effects of gibberellic and abscisic acids on germination and seedling growth of okra (Abelmoschus esculentus L.) under Salt Stress. Pertanika Journal of Tropical Agricultural Science, 42(2), 847-860. Retrieved from: https://web.a.ebscohost.com/abstract

Yohanna, J. A., \& Muhammad, A. M. (2018). Effect of seeding rate on growth and yield of okra (Abelmoschus esculantus) in Zuru Northern Guinea Savanna of Nigeria. International Journal of Scientific Research and Management, 6(2), 1-5. DOI: https://doi.org/10.18535/ijsrm/v6i2.ah01 